\title{
Citizen of the Nation: John Fletcher Lacey, Conservationist
}

\author{
Annette Gallagher , C.H.M.
}

John Fletcher Lacey represented Iowa's Sixth District in Congress for sixteen years, 1889 to 1891 and 1893 to 1907. His congressional career spanned a period of change in lowa politics. At the beginning of the twentieth century, Iowa's Republican party was split into two factions: the emerging Progressives, who embraced a reform platform, and the die-hard "Standpat" politicians, who continued to endorse traditional nineteenth-century views. Within Iowa, Lacey allied himself with the latter group; his local reputation represented him as an oldfashioned conservative, closely linked to the railroads and supportive of high protective tariffs. He labeled himself "the Standpatter from Standpatville," and is usually remembered in this role. However, in Washington, Lacey projected a far different image. Nationally he was recognized for his sponsorship of forward-looking legislation in environmental and human resource conservation. In the following article Annette Gallagher highlights this forgotten facet of Lacey's career, detailing his paradoxically progressive legislative efforts as one of the nation's earliest conservationists. $-E d$.

$\mathrm{J}_{\mathrm{o}}$ OHN FLETCHER LACEY demonstrated widely divergent interests as a political leader in Iowa and as a congressman in Washington. On the state level, he allied himself with railroad interests and remained conscious of the prejudices and demands of his constituents. On the national level, in matters unrelated to Iowa, he pursued areas of special interest which reflected both conviction 
and vision. Although Lacey strongly and çonsistently opposed the Progressive movement, he pioneered in legislative areas later identified as Progressive. His national career demonstrated an abiding interest in conservation problems, particularly those associated with wild life, forests, and parks. An enduring humanitarian concern also characterized Lacey's national political activity. Although his leadership in the areas of human rights and natural resource conservation involved no political risk in lowa, neither did it win him political advantage in the state. Colleagues in Congress, however, appreciated Lacey's national interests and accorded him greater respect than did many citizens of Iowa.

Lacey was a pioneer in the field of conservation. In fact, he has been called the "Father of American Conservation." One of Lacey's contemporaries recognized him as "one of the first to lift up his voice in Congress and ask for a stay of the hand of the destroyer." William T. Hornaday, director of the New York Zoological Park, lobbied vigorously for many of Lacey's bills and claimed that the Iowan was the first American congressman "to become an avowed champion of wildlife."

Membership on the House Public Lands Committee and twelve years service as its chairman provided Lacey a forum for his conservation interest and opinions. The Iowa congressman began his work in 1892 as a champion of bird wild life. Although he labored for eight years before achieving the passage of a conservation measure, Lacey regarded this sustained effort worthwhile and believed that the Lacey Bird and Game Act of 1900 was one of the most useful bills of his congressional career. This law received national attention as a new departure in a field in which the federal government had not previously claimed any right to legislate. To assure the constitutionality of his so-called "bird bill," Lacey based it on the interstate commerce clause of the Constitution. ${ }^{2}$

${ }^{1}$ Charles F. Lummis, photograph inscription, vol. 26, Lacey Papers, Iowa State Historical Department, Division of Historical Museum and Archives, Des Moines, Iowa (hereafter cited as LP); Tacitus Hussey, "The Old-time Trapper," Annals of Iowa 9 (January 1910): 310; William T. Hornaday, "John F. Lacey," Annals of Iowa 11 (January 1915): 582.

${ }^{2}$ John F. Lacey, "Autobiography," LP, pp. 88, 122-123; L. H. Pammel, ed., 
Lacey's bird bill was introduced in Congress in January 1900. Later known as the Lacey Act, the bill authorized the secretary of agriculture to forbid the importation of unwanted foreign birds and animals and to work for the propagation of game, song, and insect-eating wild birds in the United States. It also aimed at eliminating the interstate shipment of illegally killed game. To avoid a charge of invasion of states' rights by the federal government, the bill applied only to those states which already had game laws. ${ }^{3}$

Support for the bird bill was nationwide with many individuals and associations cooperating with Lacey to secure its passage. James ("Tama Jim") Wilson, secretary of agriculture and a fellow Iowan, offered suggestions to avoid congressional pitfalls. T. S. Palmer, assistant chief of Biological Survey in the Department of Agriculture, urged the nation's ornithologists to lend their support. Moreover, the New York Zoological Society, along with fish and game associations from Montana, Pennsylvania, and the District of Columbia, organized to apply pressure on congressmen in behalf of the bill. The League of American Sportsmen also ardently supported Lacey's bill. These organizations secured personal interviews with members of Congress, distributed thousands of pieces of literature, and contacted fish and game associations from other states for cooperation in lobbying for the bill. The Millinery Merchants' Association, composed of manufacturers of women's hats, initially opposed the bill because it outlawed the slaughter of many birds providing decorative feathers, but it withdrew its opposition when Lacey accepted an amendment permitting them to use plumage from barnyard fowl. ${ }^{4}$

On April 30, 1900 Lacey delivered a long defense of his bill in

Major John F. Lacey Memorial Volume (Cedar Rapids: The Torch Press for the Iowa Park and Forestry Association, 1915), pp. 127-135; Iowa State Register, 18 October 1900 . For a summary list of Lacey's legislation in wild life preservation, see vol. 264, LP.

${ }^{3}$ For references to Lacey's earlier attempts to secure passage of the bird bill, see: Madison Grant, New York Zoological Society, to Lacey, 23 December 1898 ; W. T. Hornaday to Lacey, 25 January 1899, vol. 250, LP. A copy of the 1900 Lacey Act is available in vol. 268, LP.

${ }^{4}$ Wilson to Lacey, 15 January 1900; Palmer to Lacey, 20 January 1900; Form 
the House. He devoted most of his speech to the section of the bill prohibiting interstate commerce in birds and game killed in violation of state laws. While claiming authority for the federal government to prevent the illegal shipment of such game across state lines, he was careful not to antagonize states' rights advocates. He clearly pointed out that under his bill the authority of the national government began where state authority ended, i.e., when the illegally killed game was ready to be shipped outside the state. Game wardens, Lacey insisted, had long wanted such a law to aid in their enforcement of state game laws. ${ }^{5}$ At the close of Lacey's defense, a vote was taken and the measure passed its first hurdle. The struggle in the Senate was much briefer than that in the House; by May 25 the Lacey Act had the approval of the senators, the signature of the president, and was the law of the land.

The new law caused varied reactions across the nation. Press comments ranged from highly laudatory remarks about Lacey to no mention of him as sponsor of the bill. ${ }^{6}$ The League of American Sportsmen expressed gratitude by soliciting donations from its members for a memorial gold watch for Lacey. Enforcement of the Lacey Act in several large cities resulted in confiscation of illegally shipped birds such as quail and doves; as many as twenty thousand were netted in a single raid. The Milliners' Association agreed to impose a five-hundred dollar fine on any member who used decorative feathers in violation of Lacey's law. In keeping with the positive aspects of the bill, thousands of game birds were brought into the United States for

letter, New York Zoological Park officers, 17 March 1900; M. J. Elrod to House Speaker D. B. Henderson, 7 April 1900; G. O. Shields, League of American Sportsmen, to Lacey, 14 April 1900, vol. 251, LP; Clipping, Millinery Trade Review, May 1900, unclassified, LP.

${ }^{5}$ Lacey's speech on the House floor, 30 April 1900, unclassified, LP. The bill provided a maximum fine of $\$ 200$ for each violation of the law.

${ }^{6}$ Iowa State Register, 18 July 1900, gave Lacey much credit. The Des Moines Leader, 2 July 1900, explained the bill, but gave its sponsor no recognition. Wallace's Farmer, 1 June 1900, defended the need for such a law, but in no way indicated that the Lacey Act had been passed. A Sioux City Journal reprint in the Oskaloosa Daily Herald, 28 July 1900, credited Lacey with service to the nation. 
propagation purposes. ${ }^{7}$ The Lacey Act was only a modest beginning in conservation. Lacey himself spoke of a state governor, whom he left unnamed, who scoffed that "Congress could do better than discuss the raising of goslings!"

Not content with one law for preservation of birds, Lacey became a champion for the protection of migratory birds and the establishment of game preserves. His interest in legislation prohibiting the shooting of birds in migration was generally ahead of that of his contemporaries. Cautioned that a federal migratory bird law would be unconstitutional Lacey replied:

Where all the states are more or less concerned in a law for the protection of all, and where mere local law is unavailing, our federal system ought to give protection. It is true that this power if it exists has not been exercised heretofore, but from time to time as our growing needs have demanded it, latent federal jurisdiction has been asserted and sustained by the courts. ${ }^{9}$

Lacey's efforts to achieve migratory bird legislation ended in failure but after leaving national office, he continued his interest in the subject and lived to see the enactment of a law such as he desired.

Lacey's labors to secure game preserves on federal land extended over a decade. Although he met consistent opposition in his endeavors, he finally achieved greater success in this field than in the area of migratory bird legislation. As early as 1894, Lacey had successfully sponsored a law which established Yellowstone Park as a breeding ground for wild game, but progress in additional legislation was slow after that date. Thus, the Iowan decided to stir the public to become interested in game preserves. He wrote articles, gave addresses, and mailed out in-

'Council Bluffs Nonpareil, 8 November 1900; Iowa State Register, 3 June 1900; Daily Capital, 6 June 1900; Jasper Y. Brinton, solicitor for game commissioners of Pennsylvania, to Lacey, 6 November 1903; John L. Hill, New York State Game Association, to George F. Hazleton, 7 February 1905, vol. 254, LP.

${ }^{8}$ As quoted in Pammel, Memorial Volume, p. 172.

'Lacey to J. W. Wadsworth, House Agriculture Committee, 11 December 1905, vol. 254, LP. 
numerable letters. ${ }^{10}$ In 1906 he proposed a letter campaign to Speaker Joseph Cannon in behalf of a bill authorizing the president to establish game preserves in national forests. While no such general bill for the establishment of game preserves became law before he left Congress, Lacey did secure the passage of bills for the establishment of game preserves in specific localities. ${ }^{11}$

Though its application was limited, Lacey took special pride in his Alaska Game Law because the need for game preservation in that remote area was great. Lacey became disturbed over the slaughter of Alaskan deer, the principal food of the natives, for hides. Indeed, William T. Hornaday compared the useless killing of Alaskan game to that which occurred earlier on the western plains of the United States. Recognition of this senseless destruction and the meagre attention paid to game laws by the territorial code of Alaska prompted Lacey to introduce the bill. Support for the Alaskan game bill was widespread, and Lacey had the rare privilege of seeing the House pass his measure without one dissenting vote. Receiving prompt Senate approval, the bill became a law in the surprisingly short span of four months. With the passage of the Alaska Game Law in 1902, the Des Moines Daily News acknowledged Lacey's growing reputation as a conservationist, editorializing that House members now assumed that any move in behalf of conservation would be inaugurated by the Iowa congressman. ${ }^{12}$

At the same time he was working for the Alaska Game Law, Lacey turned his attention to the preservation of the American buffalo, a species which by the turn of the century was in

${ }^{10}$ John Pitcher, Yellowstone superintendent, to Lacey, 28 March 1904, vol. 253, LP; Lacey's speech to Boone and Crockett Club, Washington, D.C., 27 January 1902, unclassified, LP; R. D. PAINE Outdoor Magazine, to Lacey, 20 April 1906, vol. 256, LP. For other letters see vols. 252-256, LP.

${ }^{11}$ W. T. Hornaday to Lacey, 3 July 1906, vol. 255, LP, commended Lacey for his Grand Canyon Preserve bill; Theodore Roosevelt to Lacey, 7 December 1906, vol. 256, LP, offered congratulations on the passage of the Olympic Game Preserve bill.

${ }^{12}$ Clipping, New York Herald, 12 January 1902, unclassified, LP; R. A. Frederick, U.S. attorney at Juneau, to U.S. attorney general, 23 January 1902, vol. 252, LP; Des Moines Daily News reprint in Oskaloosa Saturday Globe, 19 April 1902. 
danger of extinction. By July 1902 he had wrested a $\$ 15,000$ appropriation from Congress to be used in fencing a supervised breeding ground for buffalo within Yellowstone Park. Agriculture Secretary Wilson later confided to Lacey that he knew "of no man in public life who is doing so much towards the protection of wild creatures as you are." Being an Iowa man, Wilson continued, "I am all the more proud of it." 13 By 1906 Lacey had succeeded in the establishment of a second buffalo breeding ground in Oklahoma's Wichita Forest Reserve.

Forest preservation was still another area of conservation in which Lacey manifested early concern. In 1891 he participated in the drafting of a Public Lands Committee bill which he rightly characterized as "a first step towards a national system of forest reserves. ${ }^{14}$ It was under this statute, enacted in 1891 , that presidents were authorized to establish reserves by executive order. Several years before Theodore Roosevelt's name became associated with conservation, Lacey's interest in and knowledge of forest conservation was widely known.

In 1896 Lacey delivered the principal address before a joint meeting of the American Forestry Association and the National Geographic Society. In this address he expressed enthusiasm for conservation and called for action in the area of forest preservation. He enumerated the wanton waste of forests in the eastern United States as well as in Italy, France, and other European countries, and urged government action to end the "sin of destruction" in forests in the West. Considerable forest areas, he said, must be maintained in order to preserve the climate, soil, and wildlife of the country. Declaring that private owners could not perform "the duty of forestry in America ... only the government lives long enough to plant trees extensively," he placed the burden of conservation on government rather than individuals. In conclusion, Lacey suggested that forest control

${ }^{13}$ Wilson to Lacey, 9 May 1906, vol. 256, LP.

${ }^{14}$ John F. Lacey, "Homesteads in Forest Reserves,"' in Pammel, Memorial Volume, p. 99. 
be transferred from the Interior Department to the Department of Agriculture. ${ }^{15}$

Lacey introduced a bill requiring this transfer of authority and offered a twofold defense of the projected legislation. Most of the trained, scientific foresters in the United States were in the Agriculture Department, Lacey claimed, and he added that those in the Interior Department were, by job definition, hired to survey and dispose of public lands rather than to conserve and care for them. In a second defense of his bill, Lacey portrayed the Interior Department as overworked and burdened with responsibility for everything not assigned to other departments. Since his bill sought to reduce the authority of the Interior Department, Lacey used flattery to make the transfer palatable to the secretary of the interior. ${ }^{16}$

The second part of Lacey's transfer bill provided for the establishment of game preserves. This provision was a modification of his earlier stand on expansion of the role of the federal government under the interstate commerce clause. As drafted, this section of the forest bill required the president to consult with state governors before establishing game reserves on federal forests within their states. Although permission from the states was not necessary for action, it was "prudent" to receive such consent. On the basis of this distinction Lacey asserted: "I have never been a States' Rights man, but I have nevertheless always had the highest regard for the rights of the States." 17

Lacey's closely reasoned defense of this forest transfer bill, together with the endorsement of the interior secretary and President Roosevelt, was not adequate to overcome opposition. The transfer of forest control to the agriculture department had to await action by a later Congress.

Along with his concern for birds and forests, Lacey also was interested in national parks. A visit to Mt. Hood, which he could not see because of smoke from forest fires, convinced Lacey that the scenic wonders of America required governmental action for preservation. On one occasion, Lacey stated

${ }^{15}$ John F. Lacey, untitled address, 27 January 1896, unclassified, LP. (Excerpts from this address are in Pammel, Memorial Volume, pp. 69-77.)

${ }^{16}$ Congressional Record, 57th Congress, 1st session, \#5340, pp. 1-8.

${ }^{17}$ Ibid. 


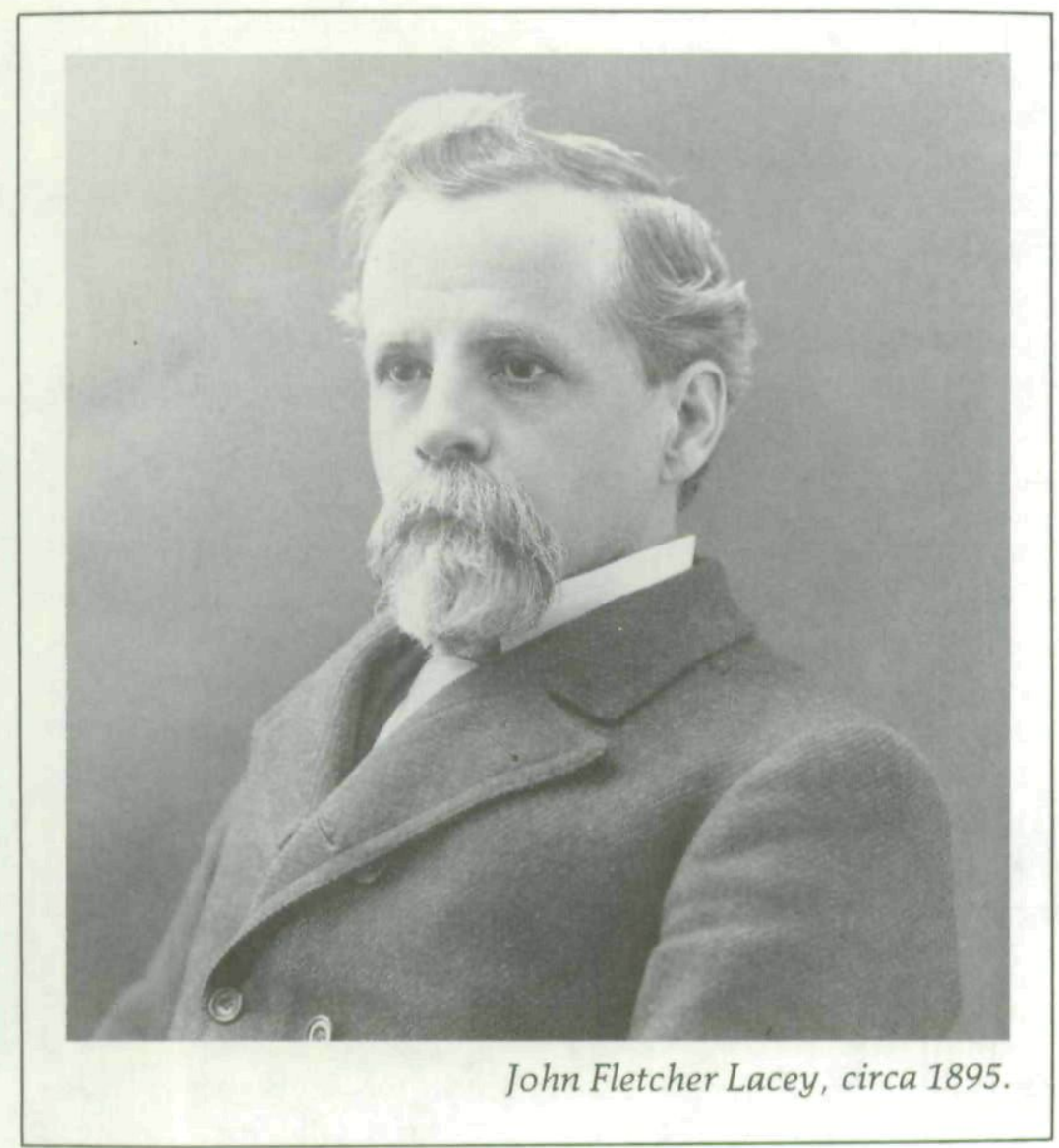

with unwitting foresight that "as our country grows, breathing places in the large cities become a matter of necessity rather than a pleasure." ${ }^{18}$ The Iowan's efforts for park legislation centered on three bills. One concerned the Petrified Forest of Arizona, and a second sought to preserve the Cliff Dwellers area of New Mexico. When both of these failed to gain acceptance Lacey introduced a bill aimed generally at the preservation of American antiquities.

During the spring of 1900 Lacey succeeded in maneuvering his Petrified Forest Park bill through the House only to see it fail in the Senate. He tried again in the fifty-seventh and fifty-eighth

${ }^{18}$ John F. Lacey, untitled manuscript on national parks, vol. 267, LP. 
Congresses, but again found the upper house unresponsive. As a result, the park bill never became law. In 1901 the Public Lands Committee favorably reported a bill for the creation of the Cliff Dwellers National Park in New Mexico. However, the House rejected the bill. He did not give up, however, and to amass first-hand data for a proposed third bill, visited the Cliff Dwellers site southwest of Santa Fe in the summer of 1902. ${ }^{19}$

Two significant achievements resulted from this trip to New Mexico. One was the introduction and passage of Lacey's bill for the Preservation of American Antiquities. Victory was in large part due to the cooperation of W. J. McGee, chief anthropologist in the Exhibits Division of the St. Louis Exposition of 1904. McGee promised to secure endorsement of Lacey's bill from scientific institutions, museums, and universities with departmental studies in archaeology or anthropology. Lacey's first attempt to pass an antiquities bill failed, but by 1905 when he tried again, McGee had secured the support of the American Archaeological Institute, the American Anthropological Association, and the Association for the Advancement of Science. With the approval and support from such respected national organizations, Lacey's bill passed both houses of Congress and received presidential approval. ${ }^{20}$

There was a second, although indirect, effect of Lacey's trip to the Southwest. The passage of his antiquities bill in turn contributed to the formation of the School of American Archaeology. Auxiliary to the American Archaeological Institute which had schools in Rome, Athens, and Jerusalem, the School of American Archaeology maintained summer institutes in Santa Fe; during the winter it explored Mexican and Central American ruins. ${ }^{21}$ The preservation of the Arizona Petrified Forest and the area of the Cliff Dwellers in New Mexico was achieved by 1906 . Under the American Antiquities Bill these

${ }^{19}$ Oskaloosa Daily Herald, 26 April 1900; Pammel, Memorial Volume, pp. 210, 233; Oskaloosa Daily Herald, 8 July 1902.

${ }^{20}$ McGee to Lacey, 8 April 1904, 9 April 1904, vol. 253, LP; McGee to Lacey, 18 January 1906, 24 January 1906, vol. 256, LP.

${ }^{21}$ Lacey attended the 1911 session of the summer school held in Rito de los Frijoles, New Mexico. See his address, "The Pajarito," n.d., in Pammel, Memorial Volume, pp. 210-219. 
two areas, together with a part of the Olympic Mountains in Washington State and over two hundred other places of ethnological interest were designated "national monuments" and preserved.

L

ACEY also was concerned about conserving human resources and promoted measures favoring those groups who wielded little political power. One of his first acts upon assuming the chairmanship of the Public Lands Committee in the fifty-fourth Congress was to endorse a bill providing free land for Oklahoma homesteaders who were too poor to pay the minimum fee assessed. Subsequently, his committee favorably reported the bill to the House, and eventually the "Free Home" Bill became a law. ${ }^{22}$

Lacey also sponsored a bill to protect mine workers. He referred to the Mine Safety Bill, passed during his first term in the House in 1890, as his "favorite bill." It called for mine inspectors, double mine shafts, and safety latches on all hoist devices. The bill specified the minimum amount of fresh air needed in proportion to the number of miners and prohibited any child under twelve years of age from working underground. Lacey's bill also authorized injunctions against mine owners who failed to comply with its provisions. The bill covered only those mines within the territories where the federal government clearly had jurisdiction, and thus it avoided conflict with the mining officials in his Iowa district. Furthermore, at the time he introduced the bill, the interstate commerce law was but three years old and its elasticity was yet to be determined. ${ }^{23}$

Lacey's fondness for the mine bill may have stemmed from the unusual circumstances accompanying its passage. The measure came before the Senate on the closing day of the last session of

${ }^{22} \mathrm{D}$. T. Flynn, Oklahoma Territory delegate to Congress, to Lacey, 19 June 1905, vol. 254, LP; Flynn to Lacey, 12 September 1906, vol. 255, LP. Both of Flynn's letters credit Lacey with securing passage of the "Free Homes" Bill.

${ }^{23} \mathrm{~A}$ copy of the bill is included in vol. 268 , LP. It was specifically aimed at the Indian Territory mines, said to be more unsafe than most. 
the fifty-first Congress. Since Lacey had lost his bid for reelection in 1890, the Mine Safety Bill had to pass Senate hurdles that day or wait for some future sponsor in the Congress. At the last minute Lacey personally entreated Senator John Sherman of Ohio to withdraw his opposition, and the bill passed one hour before adjournment. President Harrison signed it into law, but there was no time to appropriate money for its enforcement. Before the next Congress assembled, however, a mine explosion in Indian Territory took the lives of sixty-seven men. This disaster led the new Congress to allocate funds for the immediate operation of the safety law. ${ }^{24}$

Although the Mine Safety Bill did not apply to mines in Iowa's Sixth District, Lacey may have reaped some indirect political advantage from his labors. About a decade later Lacey wrote that "though many of the miners of Iowa always [had] a strong tendency to populism and visionary monetary schemes, yet they have treated me with kind consideration because of this bill." 25

Encouraged by Lacey's law, mine officials were soon urging him to amend and strengthen his safety bill. Both John Mitchell, national president of the United Mine Workers (UMW), and John P. Reese, president of UMW Local \#13 in the Sixth District, offered suggestions for improving the bill. Another mine explosion in 1902, this time in his own district, spurred Lacey into action. Some twenty men were killed when a dust explosion followed a series of blasting shots within a mine. ${ }^{26}$ After this disaster, Lacey promoted a move to fulfill the demand made by the National Miners' Convention, namely, that law compel mining companies to employ "shot-firers." 27 Within a month he maneuvered another safety bill through the House which embodied most of the requests made by UMW President

${ }^{24}$ Lacey, "Autobiography," LP, pp. 111-114.

${ }^{25}$ Ibid., p. 114.

${ }^{26}$ Mitchell to Lacey, 14 April 1900; Reese to Lacey, 29 December 1900, vol. 251, LP; Oskaloosa Daily Herald, 24 January 1902.

${ }^{27}$ Shot-firers set the dynamite charge for blasting the coal loose. Mitchell told Lacey that more miners were killed in Indian Territory than anywhere else, and that most of the deaths were due to explosions following the fire blasts. Mitchell to Lacey, 26 January 1902, vol. 252, LP. 
Mitchell. This second measure increased the minimum fresh air volume needed for each miner and added a provision for ventilation which would force air to every work area in a mine. In addition, it made the employment of trained shot-firers mandatory and provided that shots, fired daily when a mine was in operation, were not to be detonated when any miner was underground.

Lacey's bill journeyed slowly through the Senate because some senators objected, especially to the clause on shot-firing. However, he received support from the lobbying of Mitchell and local mine union officials who applied pressure on hesitant senators. Although Lacey's opponent in the 1902 race charged that he purposely limited the bill to avoid conflict within the district, the real reason for limitation probably lay with the accepted interpretation of the interstate commerce powers of the federal government. As in 1890, when Lacey wrote his first mine safety bill and again in 1900 when he carefully drafted the bird bill to avoid violating states rights, so in 1902, Lacey shunned constitutional pitfalls for his bill. Ultimately, the second mine bill passed, leading the Register and Leader to editorialize that "every recent law enacted by Congress to promote the welfare of miners has been introduced and urged ... by Lacey." 28

The Iowa congressman continued his interest in mine safety and even toyed with the idea of a bill to give cabinet status to a Department of Mines. John Mitchell, however, discouraged him from further action toward this end. He personally believed that a bill for the creation of a Bureau of Mines would more nearly succeed than one creating a department in the cabinet. Thus Lacey introduced a bill to create a Bureau of Mines within the Interior Department. The bill failed, however, and the Bureau of Mines did not become a reality until four years later. ${ }^{29}$

Another area of concern for Lacey was the plight of the

${ }^{28}$ Register and Leader, 13 October 1902.

${ }^{29}$ Mitchell to Lacey, 7 December 1905, 16 December 1905; Lacey to Mitchell, 9 December 1905, vol. 254, LP. A Register and Leader editorial (19 December 1905) reported little support for a cabinet-level Department of Mines, but predicted success for Lacey's Bureau of Mines. 
American Indian. Sixteen years of membership on the House Indian Affairs Committee and a firsthand tour of the Indian agencies of the Southwest during the summer of 1900 provided him with some knowledge of Indian problems and needs. Because he believed that education was imperative for the Indians, Lacey opposed all attempts to cut appropriations for Indian schools. He preferred small local schools to centralized boarding institutions for Indian children, pleading that children who returned home each evening would contribute to the adult education of their parents. When Indian Commissioner F. E. Leupp contemplated withdrawing the government from the care of Indian trust funds in 1905, he solicited Lacey's cooperation. Leupp asked Lacey to give his attention and the "weight of your name and influence in the House" to a bill providing for the phased distribution of tribal funds to individuals. Within a week, Lacey drafted a bill which won support from President Roosevelt, Treasury Department officials, and Leupp. ${ }^{30}$

Lacey's bill on the distribution of Indian tribal funds passed the House in 1905, but met delay in the Senate until early in 1907. Although the final version contained amendments offensive to some Indians and also to the Board of Indian Commissioners, Leupp had to accept the offending clauses or lose the entire bill. To ameliorate the situation, he requested Lacey to draft another bill giving the United States Court of Claims equity jurisdiction over cases arising from the undesirable amendments of the original bill. Lacey again agreed to cooperate, but was unable to pursue this legislation when he was not returned to office. ${ }^{31}$

In several areas of national legislation, Lacey had pursued his own vision, and left a respectable record of accomplishments.

${ }^{30}$ Oskaloosa Daily Herald, 5 March 1903; Leupp to Lacey, 25 January 1905, 30 January 1905, 2 February 1905, 14 February 1905, vol. 254, LP.

${ }^{31}$ M. E. Gates, Board of Indian Commissioners, to Lacey, 19 February 1907; S. M. Brosius, Indian Rights Association, to Lacey, 25 February 1907; Leupp to Lacey, 23 February 1907, 26 February 1907, vol. 257, LP. Also see Leupp to Lacey, 10 May 1906, vol. 255, LP, in which Leupp spoke of accepting a "halfloaf" in the bill. Typical of the disputed amendments was one which permitted the sale of timbered Indian lands for $\$ 10$ per acre when both the Indian owners and government officials judged them to be worth $\$ 100$ per acre. 
Lacey also strove to enlarge the meaning and use of the interstate commerce clause of the Constitution. This endeavor, together with his solicitude for miners and Indians and his early interest in conservation, marked him as a man of vision and concern. As Lacey soon learned, however, he enjoyed far more esteem among national political leaders than he did among party leaders and citizens of his own state.

Lacey suffered a humiliating defeat in the 1906 election. He was the only Republican congressman to lose in Iowa, and even failed to carry his home county, Mahaska. Lacey's loss was attributed to a number of causes: party factionalism, his opponent's strength as a candidate, his own long tenure in office, and local federal patronage controversies. But the major factor was, in the words of the Brooklyn Chronicle editor, Lacey's "own failure to grasp the meaning of the popular political upheavals of the past few years." He had identified himself locally with Standpat Republicanism and, in spite of his record of conservation and human rights legislation, was characterized as "a reactionary and out of all sympathy with the reform measures of the present." 32

The end of Lacey's congressional career did not signal the end of his interest and work in conservation. As a member of the League of American Sportmen's Committee on Conservation, he continued to urge legislation in two specific areas: to establish a game preserve in every national forest reserve and to enact a migratory bird law. His long-standing efforts toward the latter were realized shortly before his death in 1913 when Congress approved the Weeks-McLean migratory bird bill.

Lacey's role as a supporter of conservation spanned the years from the early 1890 s to his death in 1913 . This represented nearly a quarter century of service to the nation from which he gained little political return. Conservation was a labor of concern and devotion for Lacey. While he worked steadily to educate the public on the need for conservation, he sponsored legislation which gradually moved federal authority into areas too complex for states to handle effectively. Lacey's accomplishments were services to the nation, and not merely to Iowa. His

${ }^{32}$ Brooklyn Chronicle reprint in Register and Leader, 10 December 1906. 
state had no great forests to reserve or public lands to convert to national parks. Thus, it is not for his success in conservation leadership that Lacey is best remembered, but for the defeat of his political views. While Iowans rightly identified Lacey with railroads and hopelessly old-fashioned economic policies, they failed to give him credit for the pioneering side of his legislative work. L. H. Pammel, president of the Iowa Park Association, underscored the unselfishness and foresight of Lacey's conservation work when he wrote that "the great cause, protection of the forests, game, and the preservation of antiquities had little of interest to the average citizen of Iowa, but to the nation as a whole, in particular to generations yet to come, it will mean much." ${ }^{33}$

${ }^{33}$ Pammel, Memorial Volume, p. 36. 
Copyright of Annals of Iowa is the property of State of Iowa, by \& through the State Historical Society of Iowa and its content may not be copied or emailed to multiple sites or posted to a listserv without the copyright holder's express written permission. However, users may print, download, or email articles for individual use. 